\title{
A importância de Constantino para a Cristandade
}

Glauceni de Vasconcellos Sobrinho ${ }^{1}$

Resumo: O presente artigo tem por objetivo apresentar a importância de Constantino para a cristandade que começa com uma descrição da perseguição aos cristãos do I século d.C. a decadência do império romano anterior a Constantino, sua conversão com a criação do documento de tolerância, edito de Milão e por final sobre a arte bizantina. Enfatizando a luta de Constantino para obtenção do controle total do império romano. Analisamos os fatos a respeito da conversão de Constantino, seu domínio sobre a religião cristã agora debaixo de seu comando e da importância da arte bizantina no contexto cristão. Usando como fonte textos científicos e bibliográficos.

Palavras chaves: Império, arte, religião, poder.

\section{The importance of Constantine to Christianity}

\begin{abstract}
This article aims to present the importance of Constantine to Christianity that begins with a description of the persecution of Christians in the first century AD the decay of the Roman Empire before Constantine, its conversion with the creation of the document of tolerance, edict of Milan by the end on Byzantine art. Emphasizing Constantine's struggle for total control of the Roman Empire. We analyze the facts about Constantine's conversion, his control over the Christian religion now under his orders and the importance of Byzantine art in the Christian context. Using scientific and bibliographic texts as sources. The article starts with a description of the persecution of the Christians of the 1st century A.D. the decadence of the Roman Empire prior to Constantine, his conversion with the creation of the document of tolerance, Edict of Milan by end on the byzantine art. Emphasizing the struggle of Constantine to obtain total control of the Roman Empire.
\end{abstract}

Keywords: Empire, art, religion, power

\section{Introdução}

Muito tem-se falado sobre a perseguição aos cristãos no início da era cristã. Nesse breve artigo pretendemos falar a respeito dessa perseguição e seus desdobramentos, sobre a decadência do império romano com foco especial na arte bizantina. Fazer uma breve apresentação a respeito da conversão do imperador Constantino, bem como o edito de Milão e o desenvolvimento da arte bizantina.

\footnotetext{
${ }^{1}$ Professora no Curso Técnico de Modelagem do Vestuário, Professora e Coordenadora do Curso Técnico de Produção de Moda da Rede Estadual de Ensino de Vila Velha-ES no Centro Estadual de Ensino Técnico CEET Vasco Coutinho, graduada em Design de Moda (UVV), pós-graduada em Gestão Educacional (CESAP), Educação de Jovens e Adultos (CESAP) e mestranda em Ciências das Religiões (Unida). Contato: professoraglauceni@ gmail.com.
}

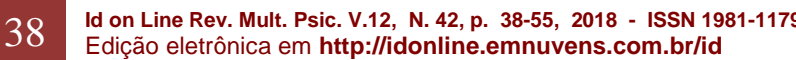




\section{Perseguição cristã}

Ao decorrer de três séculos a perseguição aos cristãos por parte do império romano fora extremamente cruel, algo sem precedente e contínuo na história. Segundo Tertuliano as mortes dos cristãos eram uma semente que se espalhava, quanto mais cristãos morriam igualmente cresciam.

A intolerância aos cristãos ao longo dos séculos já havia sido predita por Jesus Cristo, de fato os eles não foram inicialmente perseguidos pelo império romano, mas pelas autoridades religiosas da nação de Israel, "Então eles vos entregarão para serem afligidos e condenados à morte. E sereis odiados por todas as nações por serem meus seguidores"2.

Segundo parte dos estudiosos a perseguição inicialmente fora esporádica e localizada em todo território romano, até que Tibério Nero Cláudio Domiciano César, foi nomeado, imperador, principiando-se de fato a perseguição aos cristãos por parte do império, de acordo com historiadores, Nero tinha uma personalidade paranoica (Uma desestruturação psíquica que cria uma pseudo percepção da realidade que o cerca não conseguindo fazer ponte entre o real e o imaginário), ele no período ocupava a posição mais poderosa do mundo. Seu domínio iniciouse em 54 d.C. até ser destituído pelo senado em 64 d.C. Seu reinado fora definido por por assassinatos, atos de loucura e repressão em escala desmedida, a ponto de assassinar sua mãe Agripina, sua esposa Otávia e segundo historiadores ordenou o incêndio de proporções gigantescas que devastou Roma, em julho de 64 d.C. ${ }^{3}$ Para demonstrar o estado de loucura do imperador, Tácito afirma que havia rumores de que Nero ficou cantando e tocando lira enquanto a cidade queimava. ${ }^{4} \mathrm{O}$ impacto fora enorme e de acordo como esse autor escreveu: "Dos quatorze bairros de Roma, só quatro se conservaram inteiros; três ficaram completamente arrasados; e em sete só restaram escombros e vestígios de edifícios, quase totalmente consumidos pelo fogo". 5

\footnotetext{
${ }^{2}$ A BÍBLIA Almeida Corrigida, Bíblia Online: Mateus 24.9. Disponível em: <https://www.bibliaonline.com.br/acf/mat/24/09+>. Acesso em: 01 ago. 2018.

${ }^{3}$ TEIXEIRA, Raphael Leite. A Espada do Basileus: Política Imperial e a Cristianização do Exército Romano (Século Iv D.C.). Disponível em: 〈http://repositorio.ul.pt/bitstream/10451/7936/2/ulf1129460_tm.pdf〉. Acesso em: 02 ago. 2018.

4 "Nero" em Só História. Virtuous Tecnologia da Informação, 2009-2018. Disponível em: <https://www.sohistoria.com.br/biografias/nero/>. Acesso em: 02 ago. 2018.

${ }^{5}$ ANGELOZZI, Gilberto Aparecido. A águia e a cruz. Romanos e cristãos na Cidade Eterna. Disponível em: <http://www.historianet.com.br/conteudo/default.aspx?codigo=1212>. Acesso em: 02 ago. 2018.
} 
Entretanto, historiadores avaliam que esse incêndio fora acidental e não proposital da parte do imperador, porém outros estudiosos afirmam que essa hipótese é um equívoco, pois de acordo com eles o imperador teria planos para revitalização urbana da cidade, e nesse momento o pequeno grupo de cristãos caíram como um presente, Nero fez dos cristãos seu "bode expiatório" (Bode expiatório é uma expressão usada quando alguém é acusado de um delito que não fez, ou que não foi o idealizador $)^{6}$, para implantação de seu projeto e logo a tragédia do incêndio e opressão espalhou-se por todo canto. O imperador em sua sede de poder teceu em Roma um reino de terror sem limites contra os cristãos.

Certamente aqueles que professavam o cristianismo eram espancados, torturados e queimados vivos. Nero fez a escolha mais óbvia, jogar a culpa por seus devaneios em um grupo de pessoas que tinham uma religião que não se ajustava ao Panteon dos deuses greco-romano, seguidores de um crucificado, um simples carpinteiro de Israel, "fim do mundo" para os romanos, localizado na palestina. A perseguição foi incansável e impiedosa por mais de três séculos, aumentando e diminuindo, porém jamais encerrada.

De fato, existe uma indagação, no que diz respeito a perseguição. Como entender os motivos pelos quais os cristãos foram perseguidos, o porquê de tanto ódio a um grupo de homens e mulheres piedosos, com uma moral de vida voltada para o bem de seus semelhantes, sendo tratados como se não fossem seres humanos. A igreja primitiva tinha como projeto de vida ser um modelo de perfeição como fora seu Mestre Jesus Cristo. Um dos princípios mais básicos para qualquer cristão na época era servir de exemplo, obedecer às autoridades, pagar impostos, amar seus semelhantes, estender a mão aos mais necessitados, o que era feito pela grande maioria, algo contrário ao perfil do império. Eles foram perseguidos, espancados, queimados vivos ou mortos por fazer o bem. O motivo de tanta agressão não é compreensível a olhos racionais, pessoas simples que sempre estavam disponíveis para abraçar a causa de seus semelhantes, convidados a dar de si o que pudessem em favor do outro.

E muitos sinais e prodígios eram feitos entre o povo pelas mãos dos apóstolos. E estavam todos unanimemente no alpendre de Salomão. Dos outros, porém, ninguém ousava ajuntar-se a eles; mas o povo tinha-os em grande estima. E a multidão dos que criam no Senhor, tanto homens como mulheres, crescia cada vez mais. ${ }^{7}$

${ }^{6}$ SOUSA, Rainer. Como surgiu a famosa expressão 'bode expiatório'? Disponível em: $<$ https://brasilescola.uol.com.br/curiosidades/bode-expiatorio.htm>. Acesso em: 02 ago. 2018.

${ }^{7}$ A BÍBLIA Almeida Corrigida, Bíblia Online: Atos 5. Disponível em: <https://www.bibliaonline.com.br/acf/atos/5/12-14+>. Acesso em: 01 ago. 2018. 
É também por essa razão que pagais os impostos, pois os magistrados são ministros de Deus, quando exercem pontualmente esse ofício. Pagai a cada um o que lhe compete: o imposto, a quem deveis o imposto; o tributo, a quem deveis o tributo; o temor e o respeito, a quem deveis o temor e o respeito. A ninguém fiqueis devendo coisa alguma, a não ser o amor recíproco; porque aquele que ama o seu próximo cumpriu toda a lei. Pois os preceitos: Não cometerás adultério, não matarás, não furtarás, não cobiçarás, e ainda outros mandamentos que existam, eles se resumem nestas palavras: Amarás o teu próximo como a ti mesmo. ${ }^{8}$

Vale lembrar que a perseguição não era apenas por parte do império e seus imperadores, mas também por parte da população que enxergava nos cristãos uma ameaça a sua religião politeísta. Os cristãos eram "personas non grata”, recusavam-se a adorar os deuses do império, repulsavam a ideia de chamar os imperadores de senhores. Adoração a outros deuses que não fosse Jesus Cristo, era algo impensável para os cristãos dos primeiros séculos que preferiam o martírio a reverenciarem outros deuses ou praticar o culto ao imperador pessoalmente ou através de estátuas e não se curvar ao imperador deveriam arcar com as consequências, em alguns casos aguardar a morte. Por esse motivo sofreram as piores crueldades que um ser humano pode padecer; foram crucificados, queimados vivos com betume, sendo usados como "lâmpadas" para iluminar as ruas da capital romana, jogados aos leões famintos, mortos ao fio da espada, mas não antes de serem torturados ao limite máximo.

Existem algumas divergências muito interessantes em relação a perseguição aos cristãos, com exceção dos judeus, a saber o motivo pelo qual eles eram perseguidos por um império tolerante com todas as religiões do império. Uma das possibilidades em relação a perseguição pode estar ligada ao incêndio em Roma que se atribuiu à Nero, mas que o mesmo culpou o pequeno povo do caminho.

Perseveram outras hipóteses que se relacionam ao "bom andamento" da pax romana, "paz imposta pela força da nação mais forte sobre os povos derrotados, como a que vigorou nas províncias dominadas por Roma". Esse anseio por essa "paz" ao que parece levava os alguns do povo a odiarem ainda mais os cristãos pois os mesmos não partilhavam da forma de viver da maioria da população romana, o que gerava a todo tempo conflito e medo por parte de um ensino totalmente contrário ao modus vivendi do povo romano. Segundo A. N. Sherwin-

\footnotetext{
${ }^{8}$ A BÍBLIA Almeida Corrigida, Bíblia Online: Romanos 13. Disponível em: <https://www.bibliaonline.com.br/vc/rm/13/69+>. Acesso em: 01 ago. 2018.

${ }^{9}$ DA SILVA, Diogo Pereira. As Perseguições aos Cristãos no Império Romano (Séc. I-IV): Dois Modelos de Apreensão. Disponível em: <http://www.revistajesushistorico.ifcs.ufrj.br/arquivos7/ARTIGO-DIOGO-DA-SILVA.pdf>. Acesso em: 03 ago. 2018.
} 
White ${ }^{10}(1964: 25)$, sugeriu que as perseguições aos cristãos pautavam-se não na questão do ruptura da pax deorum, mas na contumácia, isto é, na tenacidade obstinada dos cristãos em não cometer apostasia e nem sacrificar as divindades do panteão greco-romano, o que não era aceito pela população do império por superstições e medo de que os cristãos pudessem trazer da parte de seus deuses alguma tragédia aos habitantes locais. Ainda assim os cristãos se mantinham alheios a cultura do império. Não partilhavam das práticas pagãs dos sacrifícios feitos em honra ao panteão dos deuses greco-romano, que contava com prostituição cultual, orgias entre outras práticas sexuais terminantemente proibidas pelo ensino das escrituras sagradas.

Conforme alguns estudiosos esses seriam um dos motivos pelos quais revela-se o ódio popular contra os cristãos, pois se por destino viessem a ocorrer algum tipo de desastre sobre o império seria culpa dos cristãos que estariam trazendo ira por parte dos deuses e por esses motivos os cristãos foram denunciados como testemunhas falsas que diziam, que os cristãos reuniam-se na calada da noite com a intenção de matarem crianças para saberem o que diziam as entranhas das mesmas; foram igualmente denunciados de inimigos do povo por sempre dizerem que o reino deles não era deste mundo, seguindo o Mestre que em suas palavras dizia que "seu reino não era deste mundo", livro do apóstolo, deixando claro a todos em seu entorno que Jesus Cristo voltará em glória e destruiria esse mundo para trazer a justiça e paz e que o reino de Cristo não teria fim.

O culto aos imperadores, era um grande problema para os cristãos pois não adorar a um imperador seria pena capital, uma afronta a um "deus vivo", as pessoas deveriam curvar-se e adorá-lo pessoalmente ou a estátuas dos mesmos espalhadas por todo império, tal prática era indiscutivelmente recusada pelos cristãos que afirmavam que Jesus era o Senhor "quod dominus noster Jesus" e não os imperadores, assim sendo, eles seguiam o ensino dos apóstolos escrito em Mateus:

Então disse Jesus aos seus discípulos: Se alguém quiser vir após mim, renuncie-se a si mesmo, tome sobre si a sua cruz, e siga-me; Porque aquele que quiser salvar a sua vida, perdê-la-á, e quem perder a sua vida por causa de mim, achá-la-á. Pois que aproveita ao homem, se ganhar o mundo inteiro, e perder a sua alma? ou que dará o homem em troca da sua alma? ${ }^{11}$

${ }^{10}$ SHERWIN-WHITE, A.N. Letters of Pliny. A historical and social commentary. Oxford: Oxford University Press, 1966. p.25.

${ }^{11}$ A BÍBLIA Almeida Corrigida, Bíblia Online: Mateus 24.9. Disponível em: <https://www.bibliaonline.com.br/acf/mt/2426+>. Acesso em: 30 jul. 2018. 
Os cristãos preferiam perder suas vidas a prostrar-se diante da imagem do imperador ou mesmo diante dele em pessoa. Os cristãos eram considerados foras da lei. Podemos inferir a respeito da comemoração feita em locais como coliseu, onde para o delírio do povo os cristãos eram postos como espetáculos, o império dava ao povo "pão e circo', e aos leões famintos o prato principal; a vida humana. Os cristãos eram expostos aos piores vitupérios, mortos por animais, em batalha contra gladiadores muito bem treinados, queimados vivos, entre outras atitudes. Adorar um único Deus era visto com muita desconfiança no império, apesar de em Roma existir o culto ao "sol invictus" (sol invencível), de origem Síria que fora introduzido no século III no império. O sol invictus estava relacionado ao zoroastrismo (religião monoteísta), culto a Mitra, mas para os pagãos era apenas mais um deus, diferentemente dos cristãos que eram somente monoteístas, adoradores de Jesus Cristo.

Portanto não ser pagão no império era algo quase impensável, pois a visão do paganismo estava intrinsecamente ligada a cultura do império, eles certamente não conseguiam entender o porquê os cristãos adoravam um homem que fora crucificado nu na palestina, local visto por Roma de forma preconceituosa. Os cristãos estavam sendo mortos por não se curvarem às ordens de um império pagão e pelo desejo de muitos da população, que não aceitavam que seus deuses devessem serem postos de lado em detrimento de um "novo" Deus. Os cristãos foram acusados de todo tipo de crimes hediondos, sendo em especial réus do crime de lesa-majestade, pois, entendendo a observância de Jesus "Dai a César o que é de César e a Deus o que é de Deus" ${ }^{\prime 2}$, negavam-se a prestar culto aos Imperadores, assim sendo sofreram as consequências por sua rejeição sentindo na própria pele as mais terríveis repercussões do ódio e desprezo do império.

Por certo, alguns autores da época detestavam a falta de inteligência em adorar essa enormidade de entidades. Citam-se aqui dois escritores que provam a inutilidade e o número de tais divindades. Tito Lívio observa de forma satírica: ${ }^{13}$ "É mais fácil achar um deus do que um homem " Lívio, falando de Atenas, capital da Grécia, diz que estava cheia de imagens de deuses

\footnotetext{
${ }^{12}$ A BÍBLIA Almeida Corrigida, Bíblia Online: Mateus 22. Disponível em: <https://www.bibliaonline.com.br/acf/mt/2221+>. Acesso em: 30 jul. 2018.

${ }^{13}$ HENRIQUE, Luiz. Paulo em Atenas: A Filosofia do Deus Desconhecido! Disponível em:

<https://www.voceparadeus.com/2015/06/paulo-em-atenas-a-filosofia-do-deus-desconhecido.html>. Acesso em: 30 jul. 2018 .
} 
e de homens enfeitados com toda a espécie de material e com toda a perícia da arte. ${ }^{14}$ : "Por todos os lados há altares, vítimas, templos e festas"15.

A pregação do evangelho de Jesus Cristo vai de encontro não somente a cultura, mas também a estrutura do império romano que por natureza era um reino de terror e opressão para maioria da população. Grande parte do império era composto por nações conquistadas que viviam em grande pobreza com benefícios apenas para as elites que dominavam esses povos. A mensagem de Cristo, era oposta ao pensar da cultura romana. A morte de um cristão era motivo de alegria, diversão aplaudida por multidões. A religião pagã estava entranhada na cultura do império. Por volta do segundo século, o autor anônimo da carta de Diogneto 120 d.C. que demonstra que a perseguição fazia parte da vida cristã. Ele escreveu a respeito dos cristãos o seguinte:

\begin{abstract}
Os cristãos, de fato, não se distinguem dos outros homens, nem por sua terra, nem por sua língua ou costumes. Com efeito, não moram em cidades próprias, nem falam língua estranha, nem têm algum modo especial de viver. Sua doutrina não foi inventada por eles, graças ao talento e a especulação de homens curiosos, nem professam, como outros, algum ensinamento humano. Pelo contrário, vivendo em casa gregas e bárbaras, conforme a sorte de cada um, e adaptando-se aos costumes do lugar quanto à roupa, ao alimento e ao resto, testemunham um modo de vida admirável e, sem dúvida, paradoxal. Vivem na sua pátria, mas como forasteiros; participam de tudo como cristãos e suportam tudo como estrangeiros. Toda pátria estrangeira é pátria deles, a cada pátria é estrangeira. Casam-se como todos e geram filhos, mas não abandonam os recém-nascidos. Põe a mesa em comum, mas não o leito; estão na carne, mas não vivem segundo a carne; moram na terra, mas têm sua cidadania no céu; obedecem às leis estabelecidas, as com sua vida ultrapassam as leis; amam a todos e são perseguidos por todos; são desconhecidos e, apesar disso, condenados; são mortos e, deste modo, lhes é dada a vida; são pobres e enriquecem a muitos; carecem de tudo e tem abundância de tudo; são desprezados e, no desprezo, tornam-se glorificados; são amaldiçoados e, depois, proclamados justos; são injuriados, e bendizem; são maltratados, e honram; fazem o bem, e são punidos como malfeitores; são condenados, e se alegram como se recebessem a vida. Pelos judeus são combatidos como estrangeiros, pelos gregos são perseguidos, a aqueles que os odeiam não saberiam dizer o motivo do ódio. ${ }^{16}$
\end{abstract}

Essa carta demonstra o grau de sofrimento da igreja em seus primórdios. Entretanto apesar de todo sofrimento teve grande crescimento a despeito das várias perseguições por

\footnotetext{
${ }^{14}$ FERREIRA,Tito Lívio. O Brasil não foi colônia. Rio de Janeiro. 2014, p.45, 27.

${ }^{15}$ CASTOLDI, Ticiano Saulo Scavazza. A Igreja que Conquistou um Império: História da

Ascensão do Cristianismo no Império Romano. Disponível em:

<https://www.univates.br/bdu/bitstream/10737/625/1/2014TicianoSauloScavazzaCastoldi.pdf> Acesso em: 30 jul. 2018.

${ }^{16}$ Carta de Diogneto - cerca do ano 120 d.C. Universidade de São Paulo - USP. Disponível em:

$<$ http://www.direitoshumanos.usp.br/index.php/Documentos-anteriores-\%C3\%A0-cria\%C3\%A7\%C3\%A3o-da-Sociedade-
} das-Na\%C3\%A7\%C3\%B5es-at\%C3\%A9-1919/carta-de-diogneto.html >. Acesso em: 30 jul. 2018. 
aproximadamente mais de três séculos. Tertuliano escreveu: "Se o rio Tigre chega às paredes, se o rio Nilo não cobre os campos, se o céu não se move ou se a terra o faz, se há fome, se há praga, o brado é rápido: 'Os cristãos aos leões!' escreveu Tertuliano ${ }^{17}$

Não bastasse os sofrimentos físicos, em 303 d.C., Diocleciano determinou a completa destruição de locais de celebração dos cristãos, bem como o sequestro de livros, cárcere do clero, expulsão de cristãos que fizessem parte das fileiras do exército. Essa foi talvez a mais cruel de todas as perseguições aos participantes do caminho, seguidores do crucificado. Entretanto apesar dessa perseguição, a mesma era encarada como um componente cotidiano da existência cristã, perder a vida naquela época era algo esperado pela maioria dos cristãos ainda que não a desejasse, mas se necessário fosse estavam preparados para tal acontecimento em suas vidas por amor ao Senhor Jesus. Finalmente em 313 deu-se fim a perseguição que fora conseguida apesar do derramamento do sangue dos mártires, pois todos os males que ocorria no império a culpa recaia sobre os cristãos. O imperador Constantino mudou a situação pondo a igreja no centro do Império.

\section{Decadência do Império Romano e a era Constantiniana}

Evidentemente diversas causas trouxeram o declínio e fim do poderoso Império Romano, que por séculos fora de fato um dos mais importantes centros de poder político e econômico do mundo. Todavia no decorrer do tempo foi perdendo sua influência política e econômica com guerras internas e ataques estrangeiros, muito em função da vastidão de seus domínios o que dificultava o controle sobre as áreas conquistadas. Não obstante para minimizar essa problemática o imperador Diocleciano criou o sistema de governo denominado tetrarquia que tinha como objetivo inicial a manutenção e controle sobre seus domínios. Esse modelo foi elaborado em duas partes, ocidente e oriente. Roma era a capital do ocidente e Bizâncio capital no oriente. Esse formato foi divido por quatro comandantes.

Por conseguinte, a esse novo padrão de governo havia um consenso entre os comandantes do império. No começo as relações entre eles eram pautadas pelo respeito, o que gerava um certo equilíbrio político e nesse ínterim cabia ao Imperador Diocleciano manter sua

\footnotetext{
${ }^{17}$ Resistência cristã, de Johan Companjen, São Paulo, Missão Portas Abertas, 2002. História da perseguição aos cristãos. Disponível em: <https://www.portasabertas.org.br/artigo/historia-da-perseguicao>. Acesso em: 30 jul. 2018. 
supremacia sobre o sistema de tetrarquia por ele implantado. Entretanto em 305, o imperador Diocleciano abdica do trono, o que gerou uma disputa interna pelo poder central encerrando a harmonia entre os quatro regentes do império. O modelo de gestão por tetrarquia possibilitou uma melhor gestão do vasto Império Romano, da mesma forma criou a possibilidade referente ao desejo de poder único, nesse momento motivado pela abdicação de Diocleciano.

A partir desse ponto observa-se o grande desequilíbrio de forças que gerou uma rede de intrigas e desejo de poder entre as partes, com crises internas que colocaram os chefes do Império uns contra os outros. Com a unificação por parte de Constantino único imperador depois de 324 d.C. No decorrer de seu reinado, Constantino aplicou-se a transformar fortemente o Império. De início mudou a formação do Senado, nos quais o conselho estava composto por 600 senadores, aumentando para 2.000. Reformou a prefeitura do pretório e mais a gestão das províncias foi delegada aos comandantes da guarda imperial que tinham amplos poderes civis, responsáveis pelas finanças e manutenção da ordem pública.

\section{Conversão de Constantino}

A história da conversão de Constantino é célebre: ocorrida no século IV d.C. quando o Império Romano se encontrava dividido em quatro partes distribuídas entre Constantino, Licínio, Maxêncio e Maximino. Constantino declarou guerra à Maxêncio que tomara parte de seu território, a Itália que de acordo com alguns historiadores na véspera da batalha, diz a tradição cristã que faltando pouco tempo para entrar em guerra com seu oponente o coimperador Maxêncio, Constantino fizera várias súplicas, conforme Eusébio de Cesareia seu biógrafo e amigo íntimo. Constantino tivera uma visão ou sonho no qual vislumbrou um símbolo XP, duas letras do alfabeto grego X (Chi) e P (ro) que entrelaçadas forma as primeiras duas letras da palavra grega "Christo" e seguiu uma voz dizendo: "por esse nome vencerás" 18 Assim sendo determinou que esse símbolo fosse pintado em todos os escudos de seu exército. Constantino após a vitória na ponte Milvio. Com a derrota e morte de Maxêncio em 312, estabeleceu com Licínio uma aliança que não duraria por muito tempo, pois ambos tinham um único objetivo. Um império, um único imperador.

${ }^{18}$ SEBASTIÃO, Wilson José. A Imagem Idealizada do Imperador Constantino no De Mortibus Persecutorum de Lactâncio (Séc. Iv D.C.). Disponível em: 〈http://www.historia.ufpr.br/monografias/2008/2_sem_2008/wilson_jose_sebastiao.pdf〉. Acesso em: 01 ago. 2018. 
Após o sonho ou visão e a vitória sobre Maxêncio, Constantino rendeu-se ao cristianismo. Alguns autores ponderam que por meio desse sonho Constantino entendeu que tinha uma missão a ser cumprida, a qual ele empreendeu em sua política na construção de um "novo império" quando tornou-se o único imperador. Abrindo amplo espaço para aqueles que durante mais de 3 séculos foram perseguidos e agora tornaram-se "a pedra principal da religião do Império Romano". Entretanto existem algumas dúvidas a respeito da conversão do imperador pois o mesmo dizia-se adorador do deus sol invictus, o que nos leva a crer que ele tinha relações ambíguas, ora adorava a Cristo, ora ao sol invictus.

\section{Edito de Milão}

Depois de anos de guerra restaram apenas dois imperadores, Constantino detinha a parte ocidental e Licínio a parte oriental. Constantino convenceu Licínio a juntos publicaram uma declaração em conjunto denominada como Édito de Milão, dando total liberdade de culto não somente aos cristãos, mas a todas as religiões do império. Esse documento foi dirigido ao governador da Bitínia, estabelecendo assim uma nova política religiosa, marcando uma nova fase para o império e para a igreja. Em 13 de junho de 313, os imperadores Constantino e Licínio promulgaram o édito de tolerância de Milão através do qual ele encerrou todo e qualquer tipo de perseguição. $\mathrm{O}$ edito foi feito nas línguas dominantes do império na época latim e grego, visando a paz civil.

Eu, Constantino Augusto, e eu, Licínio Augusto, venturosamente reunidos em Milão para discutir sobre todos os problemas referentes à segurança e ao bem público, entre outras disposições a assegurar, cremos dever regulamentar, primeiramente, o bem da maioria, que se refere ao respeito pela divindade, ou seja, garantir aos cristãos, bem como a todos, a liberdade e a possibilidade de seguir a religião de sua escolha, a fim de que tudo o que existe de divino na morada celeste possa ser benevolente e favorável a nós mesmos e a todos aqueles que se encontram sob a nossa autoridade. Este é o motivo pelo qual cremos - num desígnio salutar e muito digno - deve tomar a decisão de não recusar essa possibilidade a quem quer que seja, tenha essa pessoa ligado a sua alma à religião dos cristãos ou a qualquer outra: para que a divindade suprema - a quem prestamos uma homenagem espontânea -, em todas as coisas, possa nos testemunhar com o seu favor e a sua benevolência costumeiros. Assim, convém que Vossa Excelência saiba que decidimos suprimir todas as restrições contra os cristãos, encaminhadas a Vossa Excelência nos escritos anteriores, e abolir as determinações que nos parecem totalmente infelizes e estranhas à nossa brandura, assim como 
permitir, a partir de agora, a todos os que pretenderem seguir a religião dos cristãos, que o façam de modo livre e completo, sem serem aborrecidos ou molestados. ${ }^{19}$

Entretanto posteriormente Licínio na tentativa de trazer para si o controle total do Império sob o seu comando, preparou seu exército contra Constantino, tendo como objetivo ganhar a batalha contra Constantino, dispensou os soldados e o serviço civil da política de tolerância do Edito de Milão, permitindo a expulsão dos cristãos. Em síntese, Licínio torna-se um perseguidor quebrando o acordo do edito de Milão. Em 324 Constantino centraliza o império de vez debaixo de suas ordens, mantendo o Edito de Milão. Constantino tinha grande interesse em dar liberdade de culto aos cristãos, mas ao que parece com segundas intenções, assim sendo tirou vantagem de sua posição como chefe máximo do império intrometeu-se em questões doutrinárias que dividiam os próprios cristãos e convocou o famoso concílio de Nicéia em 325, (reunidos na cidade de Niceia da Bitínia, atual Iznik, província de Bursa, Turquia) assembleia na qual participaram os principais padres cristãos. Dando início ao escopo da doutrina cristã de forma organizada. O imperador promoveu o concílio nos padrões do senado romano, presidindo-o porém não deliberou oficialmente. Constantino sem dúvida nenhuma era um grande estrategista. Os cristãos tinham aquilo que ele mais ansiava, ser o único imperador, um só Deus, um só imperador.

Logo pode-se inferir que a partir desse momento muitos pagãos tornaram-se cristãos não por conversão verdadeira mas por medo de perseguição por parte do império, apesar do Edito de Milão conferir a todos tolerância religiosa, a população sabia que Licínio havia quebrado o contrato e por lógica posteriormente Constantino também poderia fazer o mesmo, assim sendo, muito encontravam-se de certa forma intimidados, pois o imperador tornara-se cristão ao menos publicamente; muitos pagãos tinham medo de serem mortos como os cristãos no passado, logo a opção mais sábia seria tornar-se ainda que de fachada cristão, o que em parte pode explicar a veneração aos santos ao longo dos séculos, algo que era contrário aos ensinos da igreja dos primeiros séculos mas que com a entrada de "cristãos pagãos" foi sendo alterado e em certo sentido "paganizando" a igreja.

A junção da Igreja e do Estado, firmou-se a partir de Constantino o que levou a interferência do poder estatal sobre os assuntos da Eclésia gerando ao longo dos séculos uma infinidade de problemas para a igreja por ter se aliado ao estado. Sob a égide de Constantino

\footnotetext{
${ }^{19}$ O Edito de Milão. Disponível em:<http://www.universocatolico.com.br/index.php?/pdf/o-edito-de-milao.pdf >. Acesso em:
} 30 jul. 2018. 
vários privilégios foram estendidos ao clero o que garantiu a criação de uma ordem jurídica com anuência do Estado, o que constituiu grandes patrocínios para construção de templos com recursos gerados por parte do império. Fora implantado um colossal projeto de obras com vistas a comemorar a piedade do imperador Constantino Magno (o Grande).

Quanto a conversão de Constantino, pairam várias dúvidas tendo em vista o mesmo ter sido batizado no final de sua vida, e além de nomear-se cristão dizia-se adorador do sol, o que leva a crer que ora adorava a Cristo, ora ao sol invictus, religião de viés monoteísta. Ele se considerava discípulo de Cristo, inspirado por um Deus Único, entretanto mantinha as funções de pontifex maximus (Sumo Pontífice, sacerdote do Colégio dos Pontífices, a posição religiosa mais alta do império romano, a datar do século VII a.C.) e mestre das religiões império. O historiador paulista Pedro Paulo Funari delibera a presumida conversão de Constantino como estratégia política. Conforme o autor:

Assim o imperador Constantino concedeu aos cristãos, por meio do chamado Edito de Milão, em 313, liberdade de culto. Em seguida, esse mesmo imperador procurou tirar vantagem e interveio nas questões internas que dividiam os próprios cristãos e convocou um concílio, uma assembleia da qual participavam os principais padres cristãos. Nos Concílios foram discutidas as diretrizes básicas da doutrina cristã. Depois, Constantino cuidou pessoalmente para que as determinações do concílio fossem respeitadas, ou seja, passou a ter um controle muito maior dos cristãos e suas ideias. Antes de morrer, o imperador resolveu batizar-se também. ${ }^{20}$

\section{Arte Bizantina}

A arte bizantina teve seu maior desenvolvimento em Constantinopla localizada, entre o mar negro e o egeu, o que facilitava em muito o comércio na região, fato que favoreceu enormemente a restauração da cidade, transformando-a em capital do Império romano, bem como o desenvolvimento da arte bizantina que estava intimamente relacionada ao caráter religioso.

O objetivo não é pensar somente na arte em si, mas no artista, bem como na época em que a mesma foi feita e os métodos utilizados por seus idealizadores e construtores. Referente ao corpo humano o belo é retratado em harmonia com a natureza a ordem da proporção é

\footnotetext{
${ }^{20}$ FUNARI, Pedro Paulo Abreu. Grécia e Roma: vida pública e vida privada. Cultura, pensamento e mitologia, amor e
} sexualidade. 2nd ed. São Paulo: Contexto, 2002, p. 143. 
fundamental para a construção do belo. Arte não é só beleza ou encantamento, mas também comunicação e pode ser usada como instrumento de marketing e controle social dentre outros costumes. A arte atinge pessoas de todas as culturas independentemente de crenças ou fé. A arte bizantina desperta uma emoção intensa, realista, que fala ao coração que se ajusta ao ensino do cristianismo, nessa época triunfante.

A arte bizantina em sua essência é uma arte sacra e busca a ligação entre o profano e o sagrado, revela na cultura a construção e manifestações artísticas (pintura, arquitetura, mosaico e escultura) pertinentes ao Império Bizantino (entre os séculos V e XV). Constantinopla sofreu várias influências do Oriente asiático que teve uma função de grande relevância na edificação da arte bizantina, além da cultura greco-romana pois adquiriu suas principais características por meio da arte grega e persa.

A nova capital do império romano do oriente, fora também um grande centro artístico. O Império estava por volta do século IV, sendo atacado constantemente por povos bárbaros (estrangeiros) o que levou por questões políticas e econômicas o retiro da capital do império de Roma e transferi-lo para Bizâncio, uma cidade grega, posteriormente batizada de Constantinopla em homenagem ao imperador Constantino.

O desenvolvimento das artes em Constantinopla, foi gerado na perspectiva da religião cristã, tendo em vista a mesma não estar mais sendo perseguida conforme o édito de Milão onde Constantino, promulgou em 13 de junho de 313 a tolerância e liberdade de culto para os cristãos, estendida a todo o Império. Com a não perseguição aos cristãos e a conversão do imperador em 313, possibilitou-se em muito o nascimento da arte bizantina no escopo religioso tendo como formato relevante a religião cristã. Estabeleceu-se através dessa nova arte, um estilo novo, rico em intensidade, fosse na técnica como na emoção refletida em cores, na escultura ou na arquitetura.

$\mathrm{Na}$ arte bizantina convencionou-se representar Constantino com uma auréola sobre a cabeça, comum encontrar-se em vitrais bizantinos a imagem do imperador juntamente com sua esposa ao lado do menino Jesus e da Virgem Maria. A arte bizantina recebeu influência de três vetores principais, dentre eles podemos elencar a cultura grega, romana e oriental (em especial da Síria e Ásia Menor) que contaram com a marcante presença da temática religiosa (cristianismo). 
Designamos aqui os pontos fortes da arte bizantina: Arquitetura, pintura, escultura e mosaicos. Em relação a Arquitetura ${ }^{21}$ a pedra fundamental era a presença de cúpulas que eram sustentadas por colunas. As igrejas em Constantinopla são sem dúvida um dos maiores exemplos da arquitetura bizantina pois foram projetadas em base circular, octogonal ou quadradas contendo imensas cúpulas que contavam com grandes espaços extensamente decorados, uma das referências desse modelo de arquitetura encontra-se na Basílica de Santa Sofia (localizada na atual Istambul).

Igualmente as pinturas, são de beleza incomensurável com destaque para os afrescos (pinturas aplicadas em paredes) com temas religiosos onde as imagens de Cristo e da virgem Maria são prevalentes. Haviam também pinturas feitas em madeiras, colunas generosamente decoradas com mosaicos e no chão de mármore polido. Muito da arte em bizâncio era construída em função dos emblemas; do grego que significa "imagem". Vale notar que no Ocidente, um ícone pode ser qualquer imagem (seja estátua ou pintura) de representação religiosa, e não deve ser equivocadamente percebida como um ídolo.

O mosaico é sem dúvida a expressão principal da arte bizantina, pois demonstrava a suntuosidade e o luxo do império através da arte religiosa, lembrando que o mosaico mais antigo data de 3.500 a.C. ${ }^{22}$ Em Constantinopla eles foram desenhados como arte sacra, pois sua maioria se encontrava em templos cristãos, tendo como valores a beleza, simplicidade e esplendor. A escultura bizantina caracteriza-se pela influência oriental.

A escultura ${ }^{23}$ na arte bizantina procura quebrar com as formas clássicas onde anulam as formas de busto rodada, dando ênfase a um estilo mais estilizado, esta mudança é influenciada pela fé cristã. As obras mais importantes são pequenos objetos, tais como panfletos e esculpidas em marfim, caixas de ovos de prata decorado com cenas clássicas entre outros.

A arte Bizantina não disponibilizava apenas formas para enfeitar as paredes e abóbadas, mas instruir os fiéis mostrando-lhes cenas da vida de Cristo, dos profetas e dos vários imperadores. Plasticamente o estilo bizantino na escultura deve ser considerado como uma derivação e degeneração do romano, sob a influência asiática. O mosaico bizantino em nada assemelha-se aos mosaicos romanos; são confeccionados com técnicas diferentes e seguem

\footnotetext{
21 LUCCHESI, Marco. Bizâncio. São Paulo: Record, 1996. A Arte Bizantina - Arquitetura. Disponível em: <http://www.beatrix.pro.br/index.php/a-arte-bizantina-arquitetura/, http://www.ecclesia.com.br>. Acesso em: 01 ago. 2018.

${ }^{22}$ A Arte Bizantina. Disponível em: < https://www.historiadasartes.com/nomundo/arte-medieval/arte-bizantina/>. Acesso em: 01 ago. 2018.

${ }^{23}$ A Arte Bizantina. Disponível em: < https://www.historiadasartes.com/nomundo/arte-medieval/arte-bizantina/>. Acesso em: 01 ago. 2018
} 
ritos que regem inclusive os afrescos. Neles, por exemplo, as pessoas são representadas de frente e verticalizadas para criar certa espiritualidade; a perspectiva e o volume são ignorados e o dourado é demasiadamente utilizado devido à associação com maior bem existente na terra: o ouro.

\section{Considerações Finais}

Enfim, abordar respeito das perseguições aos cristãos nos primeiros séculos da era cristã não é um dos mais fáceis assuntos, porém de suma importância com vistas trazer luz sobre quem de fato foram os cristãos dessa época e pelo que passaram para que o cristianismo chegasse até nossos dias. Uma problemática em relação a esse período é a existência de documentação incerta. Apresentamos informações que diz respeito ao declínio do grande império romano, no século IV d.C., quando o mesmo foi dividido entre império ocidental, Roma e oriental, Bizâncio, tornando-se posteriormente Constantinopla.

Antes da abdicação do Imperador Diocleciano em 305 d.C o mesmo havia dividido o império em tetrarquias, com quatro co-imperadores a saber: Constantino, Licínio, Maximiano e Maxcêncio. Doravante estabeleceu-se uma disputa interna pelo poder, onde somente um sairá vencedor, culminando com a vitória do Imperador Constantino em 324 d.C. Em 313 d.C. Constantino assina o Edito de Milão, juntamente com o Licínio, dando liberdade de culto e fim da perseguição aos cristãos, agora protegidos do Imperador que se tornara, segundo historiadores, um cristão. Desse ponto em diante a igreja obtém um lugar de destaque no império, tendo como seu maior padrinho o próprio imperador. A religião cristã deu um novo direcionamento para as artes bizantinas, vertente essa vista nas igrejas, com seus ricos templos construídos e adornados com as artes bizantinas que antes seculares, mas agora artes sacras.

\section{Referências}

FERREIRA,Tito Lívio. O Brasil não foi colônia. Rio de Janeiro. 2014, p. 45, 27.

FUNARI, Pedro Paulo Abreu. Grécia e Roma: vida pública e vida privada. Cultura, pensamento e mitologia, amor e sexualidade. 2nd ed. São Paulo: Contexto, 2002, p. 143. 
Professora no Curso Técnico de Modelagem do Vestuário, Professora e Coordenadora do Curso Técnico de Produção de Moda da Rede Estadual de Ensino de Vila Velha-ES no Centro Estadual de Ensino Técnico CEET Vasco Coutinho, graduada em Design de Moda (UVV), pósgraduada em Gestão Educacional (CESAP), Educação de Jovens e Adultos (CESAP) e mestranda em Ciências das Religiões (Unida). Contato: professoraglauceni@gmail.com.

SHERWIN-WHITE, A.N., Letters of Pliny. A historical and social commentary. Oxford: Oxford University Press, 1966. p.25.

BÍBLIA SAGRADA. Livro de Mateus. 2018. Disponível em: Disponível em: <https://www.bibliaonline.com.br/acf/mat/24/09+>. Acesso em: 01 ago. 2018.>. Acesso em: 30 jul.

2018.

BONI, Luis Alberto De. O estatuto jurídico das perseguições dos cristãos no império romano. Disponível em: <http://repositorio.ul.pt/bitstream/10451/7936/2/ulfl129460_tm.pdf>. Acesso em: 30 jul. 2018. p.8-9.

SOUSA, Rainer Gonçalves. "Como surgiu a famosa expressão 'bode expiatório'?". Brasil Escola. Disponível em: <https://brasilescola.uol.com.br/curiosidades/bode-expiatorio.htm>. Acesso em 02 ago. 2018.

A BÍBLIA Almeida Corrigida, Bíblia Online: Mateus 24.9. Disponível em: <https://www.bibliaonline.com.br/acf/mat/24/09+>. Acesso em: 01 ago. 2018.

TEIXEIRA, Raphael Leite. A Espada do Basileus: Política Imperial e a Cristianização do Exército Romano (Século Iv D.C.). Disponível em: <http://repositorio.ul.pt/bitstream/10451/7936/2/ulf1129460_tm.pdf>. Acesso em: 02 ago. 2018.

"Nero" em Só História. Virtuous Tecnologia da Informação, 2009-2018. Disponível em: <https://www.sohistoria.com.br/biografias/nero/>. Acesso em: 02 ago. 2018.

ANGELOZZI, Gilberto Aparecido. A águia e a cruz. Romanos e cristãos na Cidade Eterna. Disponível em: <http://www.historianet.com.br/conteudo/default.aspx?codigo=1212>. Acesso em: 02 ago. 2018.

SOUSA, Rainer. Como surgiu a famosa expressão 'bode expiatório'?. Disponível em: 〈https://brasilescola.uol.com.br/curiosidades/bode-expiatorio.htm〉. Acesso em: 02 ago. 2018.

A BÍBLIA Almeida Corrigida, Bíblia Online: Atos 5. Disponível em: $<$ https://www.bibliaonline.com.br/acf/atos/5/12-14+>. Acesso em: 01 ago. 2018.

A BÍBLIA Almeida Corrigida, Bíblia Online: Romanos 13. Disponível em: $<$ https://www.bibliaonline.com.br/vc/rm/13/6-9+>. Acesso ago. 2018. 
DA SILVA, Diogo Pereira. As Perseguições aos Cristãos no Império Romano (Séc. I-IV): Dois Modelos de Apreensão. Disponível em: <http://www.revistajesushistorico.ifcs.ufrj.br/arquivos7/ARTIGO-DIOGO-DA-SILVA.pdf>. Acesso em: 03 ago. 2018.

SHERWIN-WHITE, A.N. Letters of Pliny. A historical and social commentary. Oxford: Oxford University Press, 1966. p.25.

A BÍBLIA Almeida Corrigida, Bíblia Online: Mateus 24.9. Disponível em: <https://www.bibliaonline.com.br/acf/mt/24-26+>. Acesso em: 30 jul. 2018.

A BÍBLIA Almeida Corrigida, Bíblia Online: Mateus 22. Disponível em: $<$ https://www.bibliaonline.com.br/acf/mt/22-21+>. Acesso em: 30 jul. 2018.

HENRIQUE, Luiz. Paulo em Atenas: A Filosofia do Deus Desconhecido! Disponível em: $<$ https://www.voceparadeus.com/2015/06/paulo-em-atenas-a-filosofia-do-deusdesconhecido.html>. Acesso em: 30 jul. 2018.

FERREIRA, Tito Lívio. O Brasil não foi colônia. Rio de Janeiro. 2014, p.45, 27.

CASTOLDI, Ticiano Saulo Scavazza. A Igreja que Conquistou um Império: História da Ascensão do Cristianismo no Império Romano. Disponível em: $<$ https://www.univates.br/bdu/bitstream/10737/625/1/2014TicianoSauloScavazzaCastoldi.pdf $>$ Acesso em: 30 jul. 2018.

Carta de Diogneto - cerca do ano 120 d.C. Universidade de São Paulo - USP. Disponível em: <http://www.direitoshumanos.usp.br/index.php/Documentos-anteriores-\%C3\%A0cria\%C3\% A7\%C3\%A3o-da-Sociedade-das-Na\%C3\%A7\%C3\%B5es-at\%C3\%A91919/carta-de-diogneto.html >. Acesso em: 30 jul. 2018.

Resistência cristã, de Johan Companjen, São Paulo, Missão Portas Abertas, 2002. História da perseguição aos cristãos. Disponível em: <https://www.portasabertas.org.br/artigo/historia-daperseguicao>. Acesso em: 30 jul. 2018.

SEBASTIÃO, Wilson José. A Imagem Idealizada Do Imperador Constantino No De Mortibus Persecutorum De Lactâncio (Séc. Iv D.C.). Disponível em: 〈http://www.historia.ufpr.br/monografias/2008/2_sem_2008/wilson_jose_sebastiao.pdf>. Acesso em: 01 ago. 2018.

O Edito de Milão. Disponível em:<http://www.universocatolico.com.br/index.php?/pdf/oedito-de-milao.pdf>. Acesso em: 30 jul. 2018.

FUNARI, Pedro Paulo Abreu. Grécia e Roma: vida pública e vida privada. Cultura, pensamento e mitologia, amor e sexualidade. 2nd ed. São Paulo: Contexto, 2002, p. 143. 
LUCCHESI, Marco. Bizâncio. São Paulo: Record, 1996. A Arte Bizantina - Arquitetura. Disponível em: <http://www.beatrix.pro.br/index.php/a-arte-bizantina-arquitetura/, http://www.ecclesia.com.br>. Acesso em: 01 ago. 2018.

A Arte Bizantina. Disponível em: https://www.historiadasartes.com/nomundo/arte-medieval/arte-bizantina/>. Acesso em: 01 ago. 2018.

\section{Como citar este artigo (Formato ABNT):}

VACONCELLOS SOBRINHO, Glauceni de. A importância de Constantino para a cristandade. Id on Line Rev.Mult. Psic., 2018, vol.12, n.42, p.38-55. ISSN: 1981-1179.

Recebido: 07/08/2018.

Aceito: $13 / 08 / 2018$ 